\title{
Floristic study of an ultramafic formation in Sitio Magarwak, Sta. Lourdes, Puerto Princesa City, Palawan Island, Philippines
}

\author{
MARIA ELLENITA DE CASTRO ${ }^{1,2, \boldsymbol{v}}$, JOSE SANTOS CARANDANG VI ${ }^{2}$, ESPERANZA MARIBEL AGOO \\ ${ }^{1}$ Department of Forest Biological Sciences, College of Forestry and Natural Resources, University of the Philippines Los Banos. College Batong Malake, \\ Los Baños 4031, Laguna, Philippines. Tel./fax.: +63-536-2773, `email: mgdecastro1 @up.edu.ph \\ ${ }^{2}$ Department of Biology, De La Salle University. 2401 Taft Ave, Malate, Manila 1004, Metro Manila, Philippines
}

Manuscript received: 11 June 2020. Revision accepted: 25 July 2020.

\begin{abstract}
De Castro ME, Carandang VI JS, Agoo EM. 2020. Floristic study of an ultramafic formation in Sitio Magarwak, Sta. Lourdes, Puerto Princesa City, Palawan Island, Philippines. Biodiversitas 21: 3769-3779. A study was done to assess the floristic composition of an ultramafic formation in Sitio Magarwak, Barangay Sta. Lourdes, Puerto Princesa City Palawan. A total of 52 trees and shrubs representing 30 families and 48 genera was recorded in the overstorey while the ground cover was dominated by 10 species mostly from families Poaceae and Zingiberaceae. The most dominant tree species include Dillenia monantha Merr., Xanthostemon speciosus Merr. and Schima wallichii ssp. oblata (Roxb.) Kurz. with Important Value Indices (IVIs) of 15.96\%, 15.71\%, and 14.20\%, respectively. Level of endemicity was considerably high with 21 species classified as indigenous, 11 of which have their population restricted only on the island of Palawan. However, most of these endemics are now under threat based on the Updated List of Threatened Philippine Plants and their Categories (DAO No 2017-11) and the International Union for the Conservation of Nature (IUCN) Red List (2020-1). Two species are classified as 'critically endangered' (Olea palawanensis Kiew and Guioa palawanica Welzen) while the two are 'endangered' (Kibatalia stenopetala Merr. and Nepenthes philippinensis Macfarl.). Findings from this study suggest that appropriate conservation measures must be put in place to ensure protection of the native flora's remaining population from further destruction.
\end{abstract}

Keywords: Diversity indices, endemic, hyperaccumulators, Important Value Indices, ultramafic

\section{INTRODUCTION}

Ultramafics' are igneous or metamorphic rocks that contain $45 \%$ silica and high concentration of siderophilic elements such as magnesium, chromium, manganese, cobalt and nickel (Proctor 2003). Reduced productivity, high rates of endemism and stunted vegetation are some of the most notable characteristics of ultramafic formation (Bani et al. 2010). It covers only one percent of the Earth's land surface but in the context of biodiversity, ultramafics are considered noteworthy as it favors high level of endemism in spite of the low soil fertility and drier environment (Garnier et al. 2009).

In the Philippines, Mount Bloomfield in Palawan and Mount Giting-Giting in Sibuyan Island, Romblon were among the first well-studied ultramafic forests that provided basic information on the uniqueness of its vegetation (Podzorski 1985, Baker et al. 1992, Proctor 2003, Fernando et al. 2008). Stunted sclerophyllous trees, reaching only up to 2-3 meters tall and a maximum diameter at breast height $(\mathrm{dbh})$ of $46 \mathrm{~cm}$, presence of more open patches dominated by grasses and absence of woody plants were found to be distinct among Philippine ultramafics. Further works confirmed that this is due to low nutrient availability, high $\mathrm{Mg} / \mathrm{Ca}$ quotients, nickel and manganese toxicity, inadequate water supply, and frequent fire occurrences (Proctor 2000a, Proctor 2003). Consequently, this initial efforts inspired more botanical explorations that resulted in the documentation of more ultramafic environments in the various parts of the country
(Amoroso et al. 2009; Claveria et al. 2010; Fernando et al. 2013; Fernando et al. 2014; Aribal et al. 2016; Ata et al. 2016; Sarmiento and Demetillo 2017; Lillo et al. 2018; Ocon et al. 2018; Agoo and Evardone 2020; Sarmiento 2020). These local efforts confirmed the presence of distinctively stunted vegetation and the high degree of endemicity of ultramafics which also led to the discovery of new hyperaccumulator plants most of which are associated with nickel. In addition, it also proved the importance of floristic inventories to properly identify rare, native, and endemic species that necessitates immediate protection and conservation (Killeen et al. 1998). However, more work remains to be done considering that ultramafic soil covers five percent of the country's total land area (Madulid and Agoo 1997).

Palawan Island is considered the country's last frontier due to the richness in both flora and faunal diversity (Madulid 2002). But aside from its known richness in biodiversity, Palawan also hosts considerable areas of ultramafic formations not yet fully documented except the limited botanical works done in Mts. Pulgar, Victoria Range, and Bloomfield (Podzorski 1985; Reeves et al. 1992; Proctor et al. 2000a). This means that a large portion of the island's ultramafic formation remains undocumented and not yet properly taxonomized. In 2013, a Basic Resource Inventory of Sitio Magarwak, Brgy. Sta. Lourdes was initiated by the City Government of Puerto Princesa through the City Environment and Natural Resources Office. The presence of a 'special forest' dominated by Molave (Vitex parviflora A. Juss.) and classified it as Mid- 
mountain or Sub-Marginal forest was highlighted in the said report. However, it made no mention of the existing ultramafic formation as well as the uniqueness of it vegetation, hence this study. This floristic study was done to assess richness, degree of endemicity, and conservation status of the existing vegetation in the lowland ultramafics of Sitio Magarwak, Sta. Lourdes, Puerto Princesa City, Palawan Island, Philippines. It is hoped that this work's salient findings will add to the limited information known about this type of forest formation that will lead to a better understanding of their ecological values.

\section{MATERIALS AND METHODS}

\section{Study area}

The study was done in an ultramafic formation (N09 51.903', E1 18 43.546') of Sitio Magarwak, Barangay Sta. Lourdes, Puerto Princesa City, island of Palawan, Philippines. It has an elevation of about 220 meters above sea level and located approximately 18 kilometers north of the city proper (Figure 1). The area is characterized by rolling hills and flatlands which has been subjected to reforestation of fast-growing species. The area is part of the 232.74 hectares total land area of the barangay and was considered a marginalized forest. The study site belongs to Type 1 climate characterized by having dry periods from November to April and wet during the rest of the year. March is considered the driest month of the year, though intermittent rains are also experienced during the same period. The occurrence of typhoon events is rather rare in the entire Island resulting in the presence of a relatively drier environment.

\section{Procedure}

A total of 10 plots measuring $10 \mathrm{~m} \times 10 \mathrm{~m}$ were laid out approximately $200 \mathrm{~m}$ apart and all trees, shrubs, and saplings found inside were identified, counted, and measured. The common name and the total tree height were also determined. For herbs, grasses, and sedges present in the ground cover, it was determined using line intercept method using the modified procedure of Lumbres et al. (2014). Specifically, it was done by establishing a 10-m diagonal transect line inside each established plot and all plant species that touched the line were identified and counted. Plant species that occur outside the sample plots, but inside the study area were also noted for a complete assessment of the area's diversity.

The taxonomic identities of the specimens were determined with the assistance of local experts' and available published literature including Flora Malesiana Series (1995-2012) and Enumeration of Philippine Flowering Plants Volume 4 (Merrill, 1923-1926). Online literature/database like Plants of the World Online, World of Flora and Co's Digital Flora of the Philippines (Pelser et al. 2011 onwards) were likewise consulted. For the local names, Dictionary of Philippine Plant Names by Madulid (2001) was used as the main reference. Voucher specimens were kept in the herbarium of Palawan State University for future reference. Duplicate collection was made for further verification at the Philippine National Herbarium (PNH). The taxonomic/conservation status of all species collected in the field was determined using IUCN Red List (2020-1) and the Updated List of Threatened Philippine Plants and their Categories (Department of Environment and Natural Resources (DENR) Administrative Order No. 2017-11).

To determine the appropriateness of the study size that will represent the diversity of the existing vegetation, a species-area curve was plotted. This was done by getting the cumulative size of the 10 plots established and the number of species documented inside each quadrat/plot. It is expected that the larger the size of the study area, the greater is the number of species present, hence diversity is directly proportional to the size of the area covered.
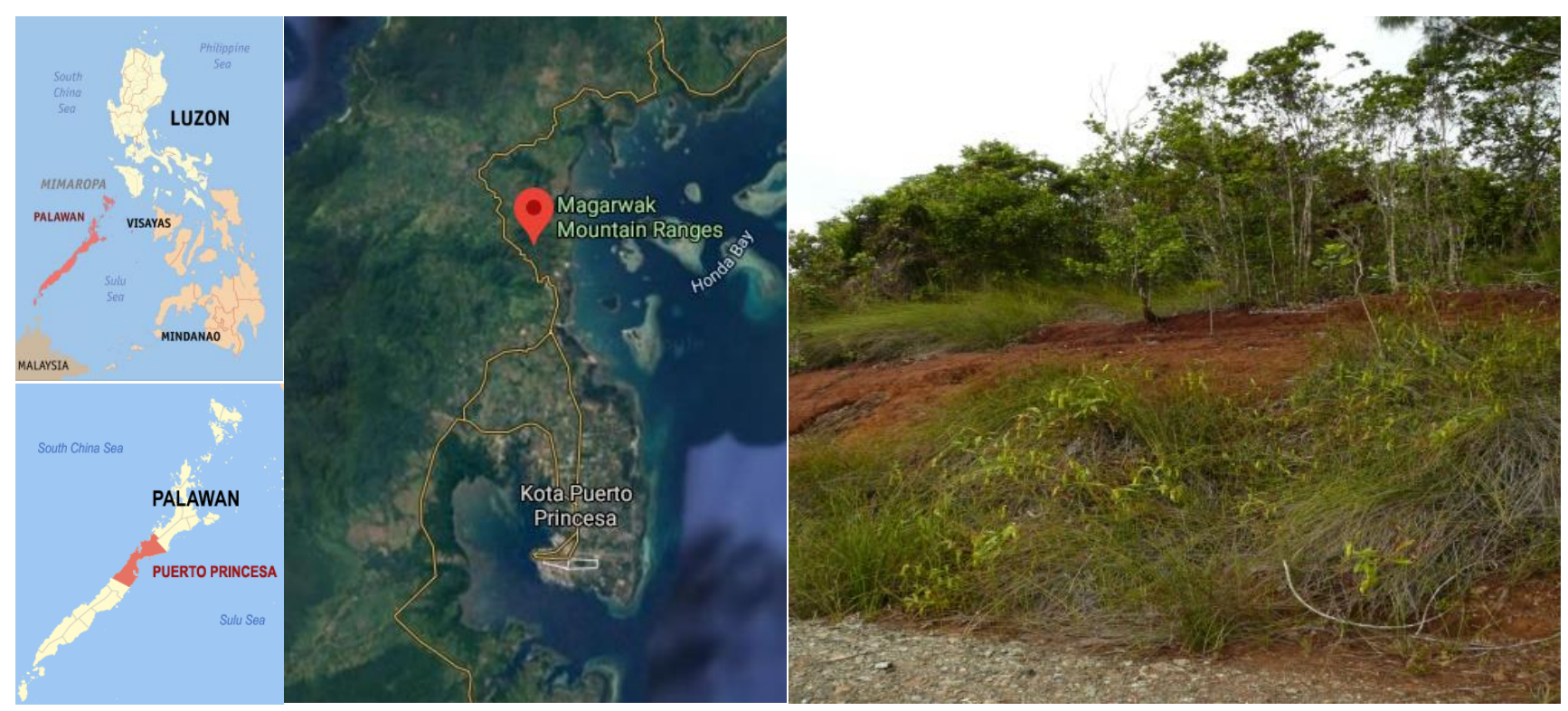

Figure 1. Location of the ultramafic formation at Sitio Magarwak, Barangay Sta. Lourdes, Puerto Princesa City (PPC), Philippines showing the vegetation and soil type 


\section{Data analysis}

Plant diversity was assessed using parameters such as species frequency, density, and importance value indices (IVI). The following parameters were determined (Replan and Malaki 2014):

Density $\left(D\right.$, tree/ $\left.\mathrm{m}^{2}\right)=\frac{\text { Number of individuals per species }}{\text { Area sampled }}$
Relative Density $(\mathrm{RD})=\frac{\text { Density for a species }}{\text { Total density for all species }} \times 100$

Frequency $(F)=\underline{\text { Number of plots in which species occur }}$ Total number of plots sampled

Relative Frequency $(\mathrm{RF})=$ Frequency value for a species $\times 100$ Total frequency for all species

Relative height $(\mathrm{RH})=\underline{\text { Summed height of all individuals for a species }} \times 100$ Summed height of all individuals for all species

Importance Value Index (IVI) $=\mathrm{RD}+\mathrm{RF}+\mathrm{RH}$.

Due to the inherent low stature and small crowned canopy, the present work used relative height instead of relative dominance (basal area) for the computation of Importance Value (IV) as patterned from Lumbres et al. (2014).

To further assess the species diversity, Shannon Diversity index $\left(\mathrm{H}^{\prime}\right)$, Evenness (E) and Simpson Index (D) were computed as follows:

$$
H^{\prime}=-\sum p_{i} \ln \left(p_{i}\right)
$$

Where: $\boldsymbol{p} \mathbf{i}$ is the proportion of individual species $\boldsymbol{i}$, and In is natural logarithm.

$$
E=\frac{H^{\prime}}{\log \mathrm{S}}
$$

Where: $\boldsymbol{H}$ is Shannon Index and $\mathbf{S}$ is the number of species

$$
D=1-\frac{\sum n(n-1)}{N(N-1)}
$$

Where: $\mathbf{n}$ is the proportion $(\mathrm{n} / \mathrm{N})$ of individuals of one particular species found and $\mathbf{N}$ is the total number of individuals found, $\boldsymbol{\Sigma}$ is still the sum of the calculations, and $\mathbf{S}$ is the number of species.

\section{RESULTS AND DISCUSSION}

\section{Floristic assessment}

A total of 52 species belonging to 30 families and 48 genera occupied the overstorey layer of an ultramafic formation of Sitio Magarwak, Brgy. Sta. Lourdes, Puerto Princesa, Palawan, Philippines (Table 1). Overall, a total of 308 individuals were recorded, mostly from the family
Rubiaceae with seven representative species followed by Fabaceae with four species. Apocynaceae, Ebenaceae, Moraceae, and Myrtaceae were equally represented with three species indicating the species' level of diversity present in the area. Some families' dominance is clear evidence of the adaptation formed to cope with the unusual edaphic and climatic conditions offered ultramafic environment (Brooks 2000; Proctor 2003; Van der Ent 2015). Species that cannot be identified to the species level due to insufficient features for proper and valid recognition are tentatively assigned to the most probable taxon (genus) only.

Results of this floristic work showed that high diversity is favored in an ultramafic forest as evidenced by the large number of plant species recorded per plot. On average, there are 11 individuals for every $20 \mathrm{~m}^{2}$ plot regardless of elevation. The vegetation in Sitio Magarwak resembles that occurring in many, but not all, ultramafic formations documented in Palawan like Mt. Pulgar, Mount Bloomfield and Mt. Victoria Range as well as other parts of the country (Reeves 1992; Proctor 2003; Fernando et al. 2008; Amoroso et al. 2009; Van der Ent 2015; Aribal et al. 2016; Ata et al. 2016; Lillo et al. 2018; Ocon et al. 2018; Sarmiento 2020). In particular, the presence of species such as Xanthostemon speciosus Merr., Scaevola micrantha C. Presl, and Brackenridgea palustris ssp. foxworthyi (Elmer) P.O. Karis was observed in the area growing sparingly from each other (Fernando et al. 2008). Soils were also noticeably dry which could partly explain the shortened height of most vegetation (pers. obs.). It has been noted that the ultramafic outcrops often support populations that are morphologically and physiologically distinct from those found on non-ultramafic soils (Galey et al. 2017).

On the other hand, the ground cover comprises 56 individuals from seven families and ten genera mostly from family Poaceae and Zingiberaceae. These two families occurrence was also noted in an earlier work in ultramafics of Palawan Island indicating their natural preference for ultramafic substrate (Reeves 2003, Fernando et al. 2008). Scleria laevis Willd. (Cyperaceae) recorded the most number of individuals across plots (18) followed by Nepenthes philippinensis Macfarl. (Nepenthaceae) with 10 individuals (Figure 2). Considering that N. philippinensis Macfarl. is an endemic and classified as endangered species in the DAO 2017-11, it is worth noting that its natural population is relatively stable in the study site. No fern or lycophyte species was documented in the area which may be attributed to geochemistry, hydrology, and fire-frequencies in an ultramafic environment (Proctor 1999). In addition, ultramafic soils is also known to harbor significantly more herbaceous and bamboo (Poaceae: Bambusoideae) species compared to ferns and bryophytes (Galey et al. 2017).

The density, frequency, and height of tree species were used to determine the Importance Value Index (IVI), a standard measure in ecology that determines the species rank relationship (Replan and Malaki 2014). Dillenia monantha Merr., Xanthostemon speciosus Merr., Schima wallichii ssp oblata (Elmer) Bloemb. were identified as the 
most dominant species with IVIs of $15.96 \%, 15.71 \%$, and $14.20 \%$, respectively (Table 2). It was hypothesized that these floral species are likely to influence the growth and survival of other species in the area due to a large number of their individuals present. It is also possible that these species were able to develop specific adaptations that permit them to thrive better in metal-rich soils compared to other species present (Baker et al. 2000, Brooks 2000, Rajakanura and Baker 2004, Van der Ent et al. 2013). Therefore, it will not be surprising if further works reveal that the dominant species also possess hyperaccumulating potential, or the ability to concentrate metals in its plants tissues at concentration above the threshold level, $(1,000$ $\mu \mathrm{g} \mathrm{g-}{ }^{1}$ for the case of Ni). Eventually, they can be utilized in phytoremediation or phytomining activities, a technology that uses plants to sequester valuable metals from ore bodies (Nkrumah et al 2017).

Figure 3 presents the six most dominant species recorded in the study site. It includes Olea palawanensis Kiew. and Brackenridgea palustris ssp. foxworthyi (Elmer) P.O.Karis in the fourth and fifth ranks generating IVI values of $14.18 \%$ and $12.57 \%$ respectively. Both species are both endemic to the island of Palawan with the former listed as 'Critically Endangered' while the latter is under the 'Vulnerable' group. O. palawanensis Kiew. belongs to olive family known to produce economically-important essential oils. As for B. palustris ssp. foxworthyi (Elmer) P.O. Karis it is a known hyperaccumulator that can concentrate $\mathrm{Ni}$ in its foliar tissues by as much as $8,000 \mu \mathrm{g}$ $\mathrm{g}^{-1}$ on dry weight basis (Reeves et al. 1992, Brooks 2000, Van der Ent et al. 2015). However, the role of hyperaccumulators in the plant community is not yet fully defined although several hypotheses were suggested most notably the defensive protection against herbivores (Proctor et al. 2000, Boyd and Jaffrè 2001, Van der Ent et al. 2015). Experts believed that large concentration of a particular metal benefited the plant as it provided protection against insect attack (Boyd 2009). An earlier work, however, proved that there exists no relationship between the rates of herbivory and leaf elemental chemistry as herbivores also attack metal-accumulating plants (Proctor 2000b). Another hypothesis for the existence of hyperaccumulators is known as 'elemental allelopathy' wherein considerable amount of leaf $\mathrm{Ni}$ is deposited directly to the soil under its canopy thereby preventing non-hyperaccumulators to coexist (Boyd 2009, Boyd and Jaffrè 2001). Contrasting evidence, however, disproved this idea attesting to the mutualistic effects of high soil Ni on the seedling growth of other species thriving under the canopy of hyperaccumulator plants (Van der Ent et al. 2015). With all these possibilities, it is highly suggested that a more detailed work must be done to determine the specific ecological role of Ni hyperaccumulators in the study site.

Dillenia monantha Merr. and X. speciosus Merr. are both endemic species classified as 'Vulnerable' under the 2017 Updated National List of Threatened Plants (DAO 2017-11). Despite their conservation status, these species managed to thrive well in unusual soil chemistry present in ultramafic forest indicating the favorable environment provided by ultramafic soils to these native species. $D$. monantha Merr. is valued in landscaping due to its attractive foliage and brightly-colored flowers while $X$. speciosus Merr. belongs to the Ironwood family hence with superior wood quality (Madulid 2002). These two species also contribute to the rich biodiversity of the island hence the proliferation of their population may be considered essential to maintains a stable community.

It will be observed that the IVIs of the five most dominant species are not very distant from each other. One plausible reason is the unique preference of these species for soils enriched with trace elements like nickel (Ni) and iron (Fe) (Proctor 2003). In addition, these dominant species are the ones most likely to maximize their ability to capture more resources' over time resulting in the proliferation of their population compared to others (Brazaz, 1996). But there is also evidences proving that to maintain survival, neighboring species engage themselves in commensalism relationships. In the ultramafics of Sabah, Malaysia, it was observed that some fern species that colonized branches of $\mathrm{Ni}$ hyperaccumulator Phyllanthus accumulated $\mathrm{Ni}$ in its tissues thereby some enhanced herbivory protection (Van der Ent et al. 2015).

For species with low IVIs, the following scenarios are possible: (i) inherent stunted growth of the species, (ii) distance of individual plants from each other, and (iii) varying age of the individual plants during the period of collection (sapling and wildling stage). The plant's ability to accumulate necessary nutrients from the soil varies not only on the plant parts, but also on the phenological development stages of its biological cycle (Xhaferri et al. 2018). As for species with lone representative, it is assumed that they are not naturally growing in the area and was only carried by various agents of dispersal and they have not yet adjusted well to the condition of the area. Therefore, more work must be done to elucidate their ecological role and contribution to the community.

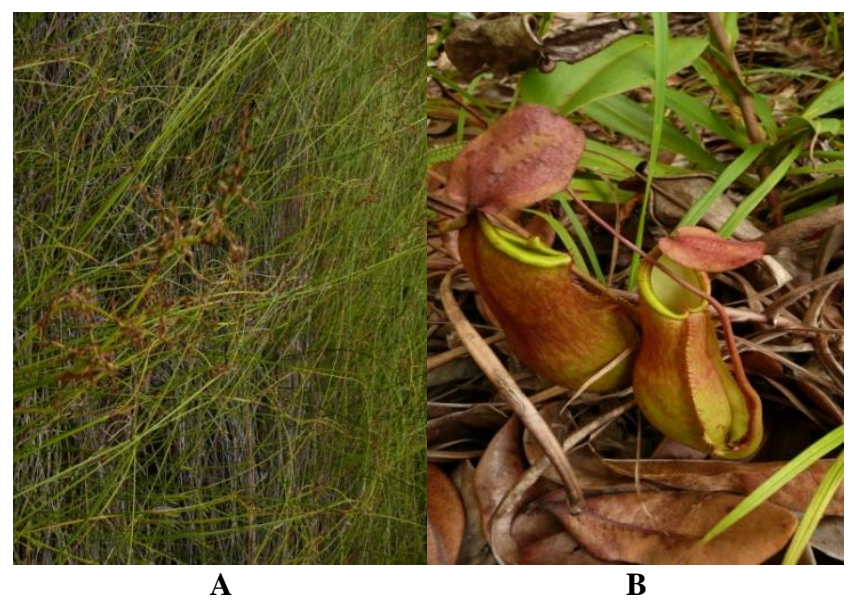

Figure 2. Dominant ground cover species present in the study site. A. Scleria laevis, B. Nepenthes philippinensis 
Table 1. Complete list of plant species in the ultramafic formation at Sitio Magarwak, Brgy. Sta. Lourdes, Puerto Princesa City with their corresponding conservation status. (Species are arranged by family)

\begin{tabular}{|c|c|c|c|c|}
\hline \multirow{2}{*}{ Family } & \multirow{2}{*}{ Scientific name } & \multirow[t]{2}{*}{ Local Name } & \multicolumn{2}{|c|}{ Conservation status } \\
\hline & & & DAO 2017-11 & IUCN (2020-1) \\
\hline \multicolumn{5}{|l|}{ Trees and shrub } \\
\hline \multirow{2}{*}{ Anacardiaceae } & Buchanania arborescens & Balinghasai & & NA \\
\hline & Mangifera sp. & & & NA \\
\hline Annonaceae & Orophea creaghii & Tabingálang & VU & NA \\
\hline \multirow{3}{*}{ Apocynaceae } & Kibatalia stenopetala & Pasnit-kitid & EN & EN \\
\hline & Amphineurion marginatum & Tandis-tandis polon & & NA \\
\hline & Urceola laevis & & VU & NA \\
\hline Burseraceae & Protium connarifolium & Márangub & VU & VU \\
\hline Calophyllaceae & Calophyllum inophyllum & Bitaog & & $\mathrm{LC}$ \\
\hline Cannabaceae & Trema eurhynchum & & & LC \\
\hline Casuarinaceae & Gymnostoma nobile & Palawan agohó & VU & NA \\
\hline Clethraceae & Clethra pulgarensis & Tagobàhi & VU & NA \\
\hline Dilleniaceae & Dillenia monantha & Kátmon-bugtóng & VU & NA \\
\hline \multirow[t]{3}{*}{ Ebenaceae } & Diospyros hebecarpa & Tulican & & $\mathrm{LC}$ \\
\hline & Diospyros kurzii & Katlima & & NA \\
\hline & Diospyros transita & & OTS & NA \\
\hline Ericaceae & Vaccinium brachytrichum & & VU & NA \\
\hline \multirow[t]{4}{*}{ Fabaceae } & Kunstleria forbesii & & VU & NA \\
\hline & Derris sp. & & & NA \\
\hline & Archidendron clypearia & & & LC \\
\hline & Dalbergia densa & & & $\mathrm{LC}$ \\
\hline Goodeniaceae & Scaevola micrantha & & & $\mathrm{LC}$ \\
\hline Hypericaceae & Cratoxylum sumatranum & Panagulingon & & $\mathrm{LC}$ \\
\hline \multirow[t]{2}{*}{ Lamiaceae } & Vitex pinnata & Malayan Teak & & $\mathrm{LC}$ \\
\hline & Premna serratifolia & Alagaw & & NA \\
\hline Lauraceae & Dehaasia cairocan & Malakadios & & NA \\
\hline Loganiaceae & Geniostoma rupestre & & & LC \\
\hline Malvaceae & Grewia multiflora & Danglin & & NA \\
\hline \multirow{3}{*}{ Moraceae } & Ficus pustulata & & & $\mathrm{LC}$ \\
\hline & Ficus sp. & & & NA \\
\hline & Streblus ilicifolius & & & $\mathrm{LC}$ \\
\hline Myrsinaceae & Ardisia sp. & & & NA \\
\hline \multirow[t]{3}{*}{ Myrtaceae } & Xanthostemon speciosus & Malapiga & VU & NT \\
\hline & Syzygium sp. & & & NA \\
\hline & Tristania sp. & & & NA \\
\hline \multirow[t]{2}{*}{ Ochnaceae } & Brackenridgea palustris ssp. foxworthyi & Bansilai & VU & NA \\
\hline & Campylospermum serratum & Alas & & $\mathrm{LC}$ \\
\hline Oleacaceae & Olea palawanensis & Palawan olive & $\mathrm{CE}$ & NA \\
\hline Phyllanthaceae & Phyllanthus balgooyi & Manglás & VU & NA \\
\hline Pittosporaceae & Pittosporum ramosii & Albòn & OTS & NA \\
\hline \multirow{8}{*}{ Rubiaceae } & Mussaenda philippica & Humbabuyin & & $\mathrm{LC}$ \\
\hline & Diplospora sessilis & & & NA \\
\hline & Canthium sp. & & & NA \\
\hline & Antirhea caudata & & & NA \\
\hline & Psydrax dicoccos & Malakape & & VU \\
\hline & Psydrax gynochthodes & Malakape & & NA \\
\hline & Psychotria sp. & & & NA \\
\hline & Morinda sp. & & & NA \\
\hline Sapindaceae & Guioa palawanica & Palawan alàhan & $\mathrm{CE}$ & $\mathrm{CR}$ \\
\hline Sapotaceae & Planchonella obovata & & & NA \\
\hline & Pleioluma firma & Bagomaho & & LC \\
\hline Theaceae & Schima wallichii ssp. oblata & & VU & NA \\
\hline Thymelaeaceae & Wikstroemia indica & Salago & & NA \\
\hline Herb, grass, sedg & roids & & & \\
\hline Asteraceae & Gynura vidaliana & & & NA \\
\hline Cyperaceae & Scleria oblata & & & NA \\
\hline Dioscoreaceae & Dioscorea palawana & Palawan ube & VU & NA \\
\hline Nepenthaeaceae & Nepenthes philippinensis & Kuong-kuong & EN & LC \\
\hline Poaceae & Dinochloa palawanensis & Palawan bikal & VU & NA \\
\hline & Panicum sp. & & & NA \\
\hline & Dinochloa sp. & & & NA \\
\hline Rubiaceae & Hedyotis sp. & & & NA \\
\hline Zingeberaceae & Alpinia foxworthyi & Langkawas & VU & NA \\
\hline & Wurfbainia palawanensis & Tagbak & VU & NA \\
\hline
\end{tabular}

**Conservation Status: NA: Not Assessed, NE: Not Evaluated, DD: Data Deficient, LC: Least Concern, OTS: Other Threatened Species, NT: Near threatened, VU: Vulnerable Species, EN: Endangered Species, CR: Critically Endangered Species, EW: Extinct in the Wild, EX: Extinct 


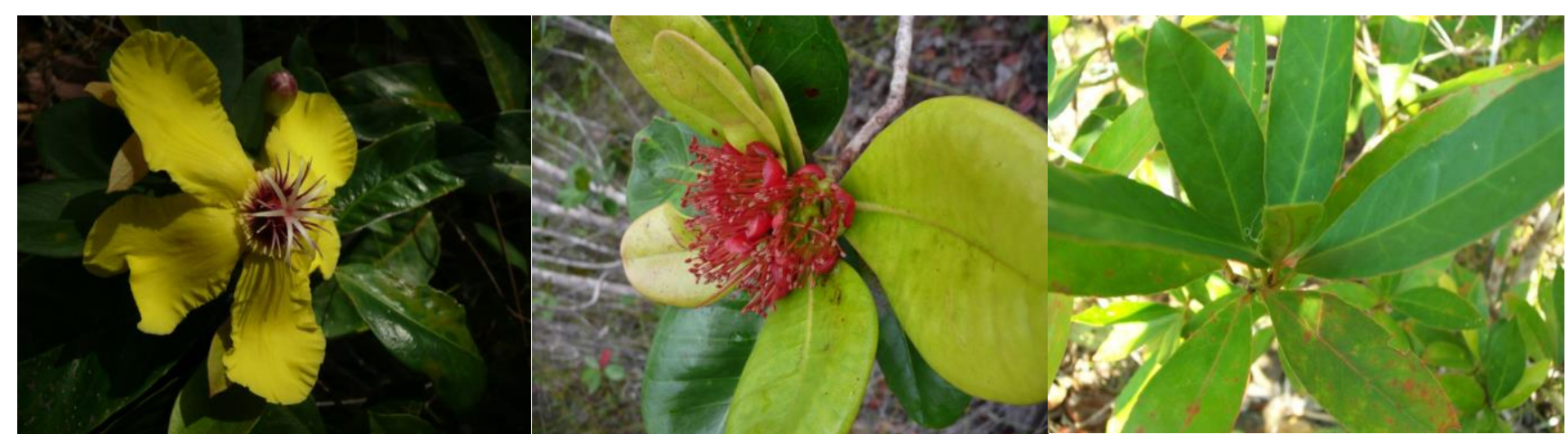

A

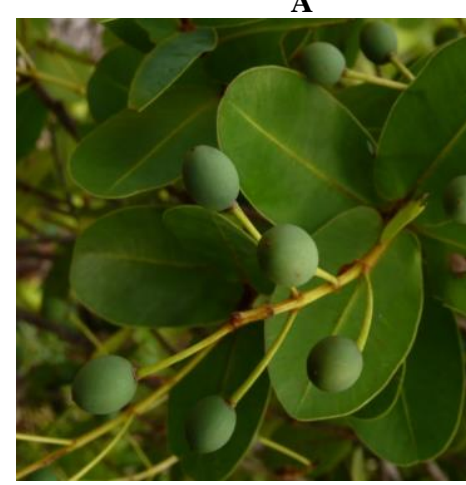

D
B

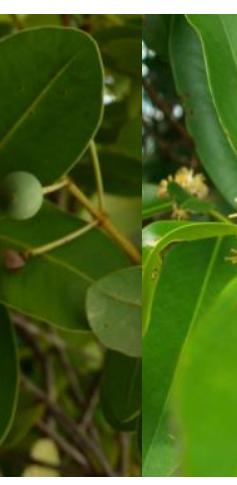

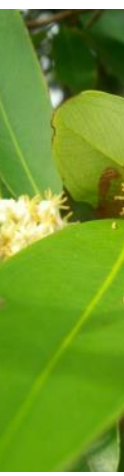

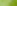

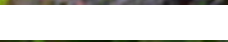

C

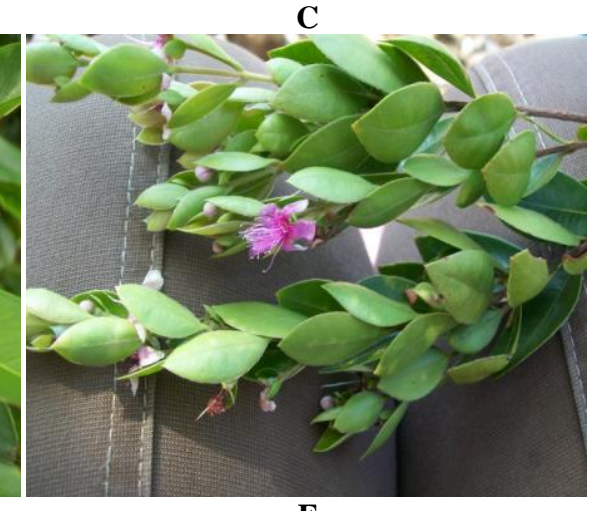

$\mathbf{F}$

Figure 3. Species with the highest Importance Value Index (IVI) in the study site. A. Dillenia monantha, B. Xanthostemon speciosus, C. Schima wallichii ssp. oblata, D. Olea palawanensis, E. Brackenridgea palustris ssp. foxworthyi, F. Vaccinium brachytrichum

Table 2. Top 10 species with the highest Importance Value Index (IVI)

\begin{tabular}{llllll}
\hline Species Name & Family & RD & RF & RH & IVI \\
\hline Dillenia monantha & Dilleneaceae & 6.76 & 6.06 & 3.14 & 15.96 \\
Xanthostemon speciosus & Myrtaceae & 8.11 & 5.05 & 2.55 & 15.71 \\
Schima wallichii ssp. oblata & Sapotaceae & 4.05 & 5.05 & 5.10 & 14.20 \\
$\begin{array}{l}\text { Olea palawanensis } \\
\text { Brackenridgea palustris }\end{array}$ & Oleacaceae & 7.77 & 5.05 & 1.36 & 14.18 \\
ssp. foxworthyi & Ochnaceae & 4.05 & 7.07 & 1.44 & 12.57 \\
Vaccinium brachytrichum & Ericaceae & 6.42 & 4.04 & 0.76 & 11.22 \\
Guioa palawanica & Sapindaceae & 3.04 & 4.04 & 1.36 & 8.44 \\
Cratoxylum sumatranum & Hypericaceae & 1.69 & 1.01 & 5.10 & 7.80 \\
Streblus ilicifolius & Moraceae & 4.73 & 2.02 & 1.70 & 8.45 \\
Diospyros hebecarpa & Ebenaceae & 0.34 & 1.01 & 3.57 & 4.92 \\
\hline
\end{tabular}

\section{Species-area curve}

Based from the plotted species-area curve, the sampling size used in the study $\left(1000 \mathrm{~m}^{2}\right)$ was sufficient to represent the diversity of the ultramafic formation in Sitio Magarwak (Figure 4). As the sampling size reached $1000 \mathrm{~m}^{2}$, the line started to plateau indicating that no additional species exists with the increasing sampling size. However, it should be noted that the species-area curve is a product of several factors more importantly the clumping or clustering of captured species in the established quadrats/plots. In general, organisms tend to concentrate in a small area due to restrictions of dispersal mechanism and available food supply. As a result, the habitat becomes less heterogeneous and uniform (Green and Ostling 2003). The type of community interactions (predatory or mutualistic) and the size of the species should also be taken into account in the assessment of species-area curves. Specific for floral species, the different strata occupied by the existing vegetation may likewise be considered a contributing factor for a highly diverse community to occupy just a small piece of land. For the case of the present study, it was noted that the area is characterized by relatively dispersed vegetation as such a larger sampling size was utilized to document the diversity of the area.

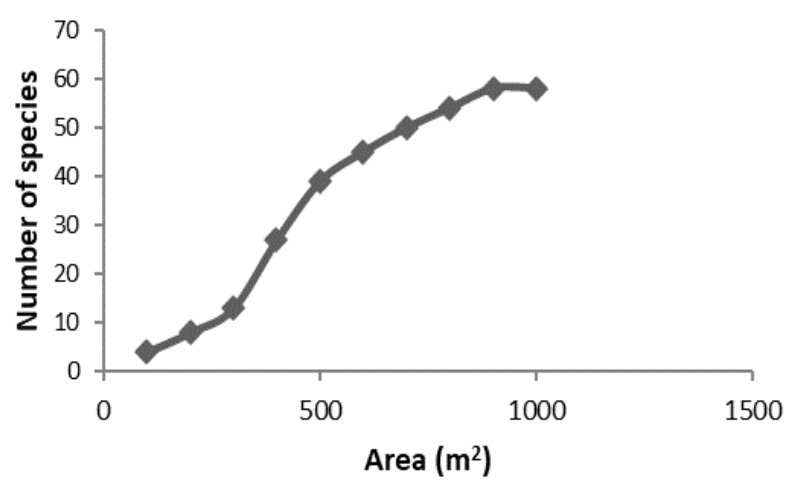

Figure 4. Species area curve of the sampling site in Sitio Magarwak, Brgy. Sta. Lourdes, Puerto Princesa City, Philippines 
Table 3. Summary of Diversity Indices for the ultramafic formation of Sitio Magarwak

\begin{tabular}{lcc}
\hline Diversity Index & Overstorey & Ground cover \\
\hline Shannon Index (H) & 3.498 & 1.822 \\
Shannon Evenness/Equitably (S) & 0.885 & 0.840 \\
Simpson Diversity Index (D) & 0.963 & 0.791 \\
\hline
\end{tabular}

\section{Diversity index}

Using species abundance and frequency, diversity indices such as Shannon $\left(\mathrm{H}^{\prime}\right)$, Evenness (E), and Simpson's (D) were also determined in this study. The ultramafic formation of Sitio Magarawak can be considered highly diverse with an $\mathrm{H}^{\prime}$ value of 3.498 for the overstorey and 1.822 for the ground cover (Table 3). This result is similar to the diversity of the lowland scrub ultramafic forest in Dinagat Island with an exceptionally high $\mathrm{H}^{\prime}$ value of 3.46 (Lillo et al. 2018). Our findings only indicate that the ultramafic of Sitio Magarwak is relatively mature as older stands are expected to host more species that interact with each other (Galey et al. 2017). But not all tropical ultramafics behave the same way. In fact, the rapid assessment of the ultramafics of Zambales and Surigao del Norte recorded a low $\mathrm{H}^{\prime}$ value of 0.6500 and 1.1071 , respectively. This scenario may be attributed to the limited number of species and the level of disturbance experienced by the species in the area. In a similar work conducted in Cagdianao, Claver Surigao del Norte, an average $\mathrm{H}^{\prime}$ value of 0.9867 was generated reflecting the low diversity in the area (Ocon et al. 2018). The shortage of major soil nutrients and the absence of mycorrhizal association of the plant species in the area are being considered as the main reasons cited by the authors. Our result showed evidence that despite the presence of several edaphic stressors, the community can still be diverse and complex (QuinetalaSabaris et al. 2020).

The computed Simpson index (D) value for the overstorey vegetation was also high at 0.963 implying the presence of several dominant species in the community that is likely to control the community. As for the 15 species with lone representative, although their significance has not yet been fully assessed, it is possible that are equally important to the stability of the community since some of them occupied the canopy layer like Gymnostoma nobile Whitmore L.A.S. Johnson (Casuarinaceae) that provide some protection to the low lying vegetation. Likewise, Evenness (E) Index for overstorey (0.885) and ground cover $(0.840)$ concur with the results of the other diversity indices giving an overall impression that ultramafic soil is highly productive and stable. However, it should be pointed out that there is an array of factors that influence diversity in an ultramafic environment (Ata et al. 2016). Soil chemistry, particularly soil $\mathrm{pH}$ and organic matter content has been considered as the most critical factor for the survival of the vegetation in the ultramafic forest. It was noted that there is an indirect relationship between metal solubility and soil $\mathrm{pH}$, that is, higher uptake of certain elements at a much lower $\mathrm{pH}$ level (Kabata-Pendias 2001). Frequent rainfall events likewise favor higher diversity due to the presence of water needed for fast growth (Proctor 1999). Therefore, ultramafics with frequent rainfall events may expect to have higher diversity compared to drier areas. In addition, geologic events related to the formation of an ultramafic also accounts for the difference in the diversity of ultramafic formations. A comparison of species diversity in ultramafic forest of Zambales and Surigao del Norte noted the difference in the species composition which was partly attributed to the ultramafic complexes' ages and possible lithospheric sources (Ata et al. 2016). Ultramafic formations regardless of location may share a distinct suite of chemical and physical features but tropical ultramafic soils are unique in elemental content, moisture, organic matter content, and soil pedology (Lewis and Bradfield. 2003, Galey et al. 2017). Based on these generalizations, it is safe to assume that the high diversity of the ultramafic formation in Sitio Magarwak is a product of all the contributing factors mentioned above.

\section{Biodiversity value}

The ecological significance of any land formation relies not only on species richness but also on the number of native, endemic, and even threatened species present. Native species may include both endemic and non-endemic indigenous species that can extend its population outside its natural geographic range while endemics are those whose distribution is strictly confined within specific geographic range or areas like island or land formation (Replan and Malaki 2017, Lillo et al. 2018). The Philippines is home to more than 3500 indigenous (native) species, $89.96 \%$ of which are classified as angiosperms, $0.17 \%$ are gymnosperm and $9.87 \%$ are pteridophytes (Madulid 1991, Amoroso et al. 2009, Lillo et al. 2018). In the present work, 22 species are indigenous to the Philippines, 11 of which have their population restricted only on the island of Palawan (Table 4). Included in the list are six endemic herbs and grasses and their presence can be influential for the survival of its associated species as they dominate the ground cover. In a similar study done in Carrascal, Surigao del Sur, a total of 46 out of 48 recorded species were found to be native to the Philippines of which 50\% are endemic or exclusively found in the country (Sarmiento 2020).

It must be pointed, however, that the category of "endemic" is largely based on the published biodiversity data, recent taxonomic revisions, nomenclatural changes, and new evidence from various disciplines used in systematics (Replan and Malaki 2017). This means that there is a high possibility that a large number of native species remain undiscovered and not yet taxonomized, hence, the actual number of endemics may even be higher than what is currently reported. 
Table 4. List of Philippine Endemic Species in the study site arranged according to family. Asterisk (*) means the species is endemic to Palawan Island only

\begin{tabular}{lll}
\hline Species name & Family & Local name \\
\hline Kibatalia stenopetala & Apocynaceae & Pasnit-kitid \\
Gynura vidaliana & Asteraceae & \\
Protium connarifolium* & Burseraceae & Marangub \\
Clethra pulgarensis* & Clethraceae & Tagobahi \\
Dillenia monantha & Dilleneaceae & Katmon bugtong \\
Dioscorea palawana* & Dioscoreaceae & Palawan ube \\
Diospyros transita* & Ebenaceae & \\
Vaccinium brachytrichum & Ericaceae & \\
Scaevola micrantha & Goodeniaceae & \\
Ficus pustulata & Moraceae & \\
Xanthostemon speciosus & Myrtaceae & Malapiga \\
Nepenthes philippinensis & Nepenthaceae & Kuong-kuong \\
Brackenridgea palustris & Ochnaceae & Bansilai \\
ssp foxworthyi* & & \\
Olea palawanensis $*$ & Oleaceae & Palawan olive \\
Pittosporum ramosii & Pittosporaceae & Albòn \\
Dinochloa palawanensis* & Poaceae & Palawan bikal \\
Mussaenda philippica & Rubiaceae & Humbabuyin \\
Diplospora sessilis & Rubiaceae & \\
Antirhea caudata* & Rubiaceae & \\
Guioa palawanica* & Sapindaceae & Palawan alahan \\
Alpinia foxworthyi* & Zingiberaceae & Langkawas \\
Wurfbainia palawanensis $*$ & Zingiberaceae & Tagbak \\
\hline
\end{tabular}

Langenberger (2004) emphasized the diversity of Philippine endemic flora is not properly reported due to the following: (i) most of the floristic studies done focused only on trees $(\mathrm{dbh}>10 \mathrm{~cm})$ or large species but in reality, smaller trees and other life forms account for the bulk of species present in any forest formation, (ii) plant diversity studies are usually conducted in higher elevation with little attention to the lowland forest that experience a more serious threat brought about by anthropogenic forces, (iii) irresponsible use of local names resulting to confusion in understanding Philippine forest vegetation and ecology, and (iv) existence of several independent floristic studies that are not properly published in a way that the science community can access the study. Unless these problems are addressed, the rich diversity of Philippine flora will not be recognized properly by the international scientific community.

The condition of most endemic species in the study site may be considered alarming. In particular, a total of 22 species are in the DAO 2017-11 list while 20 species were assessed by IUCN and included in their Red List (2020-1). Kibatalia stenopetala Merr. (Apocynaceae) and Guioa palawanica Welzen (Sapindaceae) are both noteworthy species as the two references used concur in their classification, with the former classified under 'Critically Endangered' while the latter was identified as an 'Endangered' species. This means that K. stenopetala Merr. faces an extremely high risk of extinction in the wild if no conservation measures will be done soon. Unfortunately, local people serve as one of the major threats to conservation as indiscriminate collection of valuable plant species for house construction and charcoal-making are quite rampant in the area (pers. obs.). Another species under the 'Endangered' category (DAO 2017-11) is $O$. palawanensis Kiew (Oleaceae) but surprisingly it was not listed in the IUCN Red List. As noted earlier, the species ranks fourth among the most important species in the area with an IVI of $14.18 \%$, and its continuous proliferation in the ultramafic soils only proved its preference to such type of soil (Table 2). On the other hand, N.philippinensis Macfarl. is the only ground cover vegetation included in the 'Endangered' list of DAO 2017-11 but it is considered dominant ground cover species in the area next to $S$. laevis Willd. This species was recorded as early during the 1984 botanical expedition in Palawan (Podzorski 1985, Fernando et al. 2008), hence it can be used as an indicator species of ultramafic environment.

Under the 'Vulnerable' category of DAO 2017-11, three species with the highest IVIs are identified together with four species of herbs and bamboo such as Dioscorea palawana Prain \& Brukill, Dinochloa palawanensis (Gamble) S. Dransf., Alpinia foxworthyi Ridl. and Wurfbainia palawanensis (Elmer) Skornick. \& A.D.Poulsen. In the IUCN Red List, however, only three species were classified as 'Vulnerable' category and the rest were either placed under 'Least Concern' or completely not assessed indicating the need for a more extensive review. Nevertheless, the result of this work should serve as a red flag to the concerned institutions to come up with specific conservation plans to prevent the worsening of the situation which can be in the form of local directives that must be enacted by the local government units (LGUs).

\section{Discussion}

Our study presented both similarities and uniqueness of the ultramafic formation of Sitio Magarwak with other ultramafic formations documented. The high diversity of the area which was found to be similar in the ultramafics of Dinagat Island indicates the association of several species to a metal-rich soil (Lillio et al. 2018). It was evident in both sites it was evident that specific morphological adaptations are present among native vegetation that allows them to survive in the unusual edaphic and climatic conditions present. Among these adaptations include low plant stature, small crowned canopy, and glaucous (darkgreen) leaves (Brady et al. 2005). The high diversity of the ultramafic formation in Sitio Magarwak is also comparable to other forest types documented in the Philippines as well as other parts of the world (Amoroso et al. 2009; Lumbres et al. 2014; Replan and Malaki 2017; Medecilo and Lagat 2017; Tadesse et al. 2017; Lillo et al. 2018). Endemism was also highly evident in the ultramafics of Magarwak with the presence of more than 20 out of 62 species documented in the area. Similar findings were also noted in other ultramafic formations in the country as well as those observed in New Caledonia, Cuba, Mediterranean as well as South Africa and Australia. (Arabal 2016; Galey et al. 2017; Sarmiento and Demetillo 2017; Sarmiento 2020). The restriction of several endemic species in an ultramafic environment is being considered as a direct result of their 
slow growth compared to other species that can thrive in soil with more favorable conditions (Anacker 2014).

Most of the early works that documented the vegetation in ultramafics in the country noted the distinct variation but failed to explain the mechanism behind it (Baker et al. 1992; Proctor et al. 1999; Fernando et al. 2008; Ata et al. 2016; Sarmiento and Demetillo 2017; Lillo et al. 2018; Sarmiento 2020). In the present work, we provide information on the distinct floral composition in one of the lowland ultramafic formations of Palawan which has not yet been reported. Ultramafic formations in Palawan are one of the earliest explored in South East Asia, however, much of the works were done on high elevation mountains hence different plant composition was characterized. The ultramafic of Sitio Magarwak is highly accessible to humans therefore a distinct formation was documented. It is noteworthy that at least two of the identified $\mathrm{Ni}$ hyperaccumulator plants are thriving well in the study site, which is a good indication that other potential metal-eating plants may also be present and remains undiscovered. Most of the recent explorations done in Philippine ultramafics led to the discovery of new $\mathrm{Ni}$ hyperaccumulator plants that can be utilized for phytoremediation or phytoextraction activities. In fact, the assessment of Acoje mine site in Zambales (Luzon) resulted in the identification of $28 \mathrm{Ni}$ hyperacumulators that has the capacity to absorb $\mathrm{Ni}$ $>10,000 \mu \mathrm{g} / \mathrm{g} \mathrm{Ni}$ in its aboveground (Van der Ent et al. 2012; Fernando et al. 2013). In Manacani Island, Eastern Samar, Evardone, and Agoo (2020) also identified fifteen (15) hemi-accumulators (>100-1,000 $\mu \mathrm{g} / \mathrm{g})$ with Vitex parviflora considered as the most notable. In a similar effort, new metallophytes were discovered in $\mathrm{Fe}$ and $\mathrm{Cu}$ enriched environments of Brookes Point, Palawan, and Mankayan, Benguet (Claveria et al. 2010).

The presence of species that were only identified up to genus level indicates that the level of endemism in the study site may even be higher than the current estimate. This in turn necessitates more extensive taxonomic works and botanical exploration to properly account endemic species in the area. However, since most of the endemics documented are now facing threats due to over-exploitation and indiscriminate collection among local people, the risk of losing valuable species is relatively high. Such is the case of the newly discovered $\mathrm{Ni}$ hyperaccumulator Phyllanthus rufuschaneyi in Kinabalu Park, Sabah, Malaysia (Bouman et al. 2018). The natural population of the said species was found only in patches of the remaining scrub that are severely affected by over-exploitation and human-induced forest fires. The lack of awareness and proper recognition of the ecological significance of the endemic species may be considered as one of the major reasons for the continuous decline in the population of native species in the wild. Similar situation was faced by the newly-discovered $\mathrm{Ni}$ hyperaccumulator plant Rinorea niccolifera Fernando (Violaceae) in Zambales, Luzon, Philippines (Fernando et al. 2014). Due to serious habitat fragmentation, the IUCN Red List (IUCN 2012) classified it under 'Endangered'. It is possible that the ultramafic forest of Sitio Magarwak houses a plant with contrasting hyperaccumulation potential like Dichapetalum gelonioides
(Roxb) Engl. but this remains to be undiscovered (Nkrumah et al. 2018). A much better possibility is the occurrence of a multi-element hyperaccumulating plantlike Glochidion cf. sericeum J.R.Forst. \& G.Forst. that can be utilized for environmental clean-up (Van der Ent et al. 2018), hence, more follow-up works is needed. The information presented in this work suggests that appropriate conservation management strategies must be imposed immediately to ensure the protection and conservation of the endemic species. Given the accessibility of the area, this ultramafic formation should also be considered as a long-term ecological plot that will be devoted to more studies that will provide strong evidence on the significance of its unique vegetation.

In conclusion, a total of 62 species belonging to 37 families were documented in the ultramafic forest of Sitio Magarwak, Brgy. Sta. Lourdes, in Puerto Princesa City, island of Palawan. The results of this present work complement the findings of the 2013 Resource Basic Inventory of Sitio Magarwak which documented the presence of several valuable endemic species in the area. However, since most of the native species recorded are now facing threats a strict implementation of necessary protection measures must be put in place immediately. Concerned government agencies in the locality should also restrict access to the area to prevent further destruction and disturbance of the existing vegetation.

\section{ACKNOWLEDGEMENTS}

The first author would like to acknowledge the Department of Science and Technology, Science Education Institute for the provision of the Ph.D. scholarship to complete this undertaking. The Palawan Council for Sustainable Development (PCSD) and the MENRO-Puerto Princesa City are likewise acknowledged for permits and technical assistance during the conduct of the study. Special thanks go to father and son, Reynaldo Majaducon, and the late RD Majaducon for all their assistance during the conduct of all the fieldwork related to this study. Lastly, Danilo Tandang of the Philippine National Museum is acknowledged for his assistance during the reconnaissance visit prior to the research's actual conduct.

\section{REFERENCES}

Aribal LG, Porot JCD, Paquit JA, Pabiona MG. 2016. The edaphicendemics in the metal-rich soils of Mt. Kiamo in Malaybalay, Bukidnon, Philippines. Asian J. Biodivers. 7 (1): 31-46. DOI: 10.7828/ajob.v7i1.865

Ata JP, Luna AC, Tinio CE, Quimado MO, Maldia LS, Abasolo WP, Fernando ES. 2016. Rapid assessment of plant diversity in ultramafic soil environments in Zambales and Surigao del Norte, Philippines. Asian J Bio 7 (1): 4-16. DOI: 10.7828/ajob.v7i1.864

Amoroso VB, Obsioma LD, Arlalejo JB, Aspiras RA, Capili DP, Polizon JJA, Sumile EB. 2009. Inventory and conservation of endangered, endemic and economically important flora of Hamiguitan Range, southern Philippines. Blumea 54: 71-76. DOI: 10.3767/000651909X474113

Anacker BL.2014. The nature of serpentine endemism. Am J Bot 101: 219-224. DOI: 10.3732/ajb.1300349. 
Baker AJM, Proctor J, van Balgooy MMJ, Reeves RD.1992. Hyperaccumulation of Nickel by the Flora of the Ultramafcs of Palawan, Republic of the Philippines. In: Baker AJM, Proctor J, Reeves RD (eds.) The vegetation of ultramafic (serpentine) soils Proceedings of the First International Conference on Serpentine Ecology. The University of California Davis. June 19-22, 1991.

Baker AJM, MacGrath SP, Reeves RD, Smith JAC. 2000. Metal hyperaccumulator plants: A review of the ecology and physiology of a biological resource for phytoremediation of metal-polluted soils. In Phytoremediation of Contaminated Soil and Water. Terry $\mathrm{N}$, Bañuelos GS eds. Taylor and Francis, United States of America.

Bani A, Pavlova D, Echevarria G, Mullaj A, Reeves Rd, Morel JL, Sulçe S. 2010. Nickel hyperaccumulation by the species of Alyssum and Thlaspi (Brassicaceae) from the ultramafic soils of the Balkans. Botanica Serbica 34 (1): 3-14.

Bouman R, Van Welzen P, Surnail S, Echevarria G, Erskine PD, van de Ent A. 2018. Phyllanthus rufuschaneyi: new nickel hyperaccumulato from Sabah (Borneo Island) with potential for tropical agromining. Bot. Stud 59: 9. DOI: 10.1186/240529-018-0225-y.

Boyd RS. 2009. High-nickel insects and nickel hyperaccumulator plants: A review. Insect Sci 16 (1): 19-31. DOI: 10.1111/j.1744 7917.2009.00250.x.

Boyd RS, Jaffrè T. 2001. Phyto-enrichment of soil Ni content by Sebertia acuminata in New Caledonia and the concept of elemental allelopathy. S. Afr. Sci 97: 535-538.

Brady KU, Kruckeberg AR, Bradshaw Jr HD. 2005. Evolutionary ecology of plant adaptation to serpentine soils. Ann Rev Ecol Evol Syst 36: $243 \mathrm{e} 266$

Brazaz FA. 1996. Plants in Changing Environment: Linking Physiological, Population and Community Ecology. Cambridge Univ. Press, UK.

Brooks RR. 2000. Plants that Hyperaccumulate Heavy Metals (their Role in Phytoremediation, Microbiology, Archaeology, Mineral Exploration and Phytomining). CAB International, New York.

City Environment and Natural Resources. Department of Interior and Local Government (DLIG). 2013. Resource Basic Inventory of Sitio. Magarwak, Barangay Sta. Lourdes, Puerto Princesa City.

Claveria RR, De Los Santos CY, Teodoro KB, Rellosa MA, Valera NS. 2010. The identification of metallophytes in the $\mathrm{Fe}$ and $\mathrm{Cu}$ enriched environments of Brookes Point, Palawan and Mankayan, Benguet and their implications to phytoremediation. Science Diliman 21 (2): 1-12.

DENR [Department of Environment and Natural Resources]. Administrative Order 2017-11. 2017. Updated national list of threatened Philippine plants and their categories. Department of Environment and Natural Resources, Philippines.

Evardone MC, Agoo EMG. 2020. Taxonomic survey of nickel accumulating plants in a mining site of Manicani Island, Guiuan, Eastern Samar, Philippines. Intl J Biosci 16 (1): 83-92. DOI: 10.12692/ijb/16.1.83-92

Fernando ES, Suh MH, Lee J, Lee DK. 2008. Forest Formations of the Philippines. ASEAN Korea Environmental Cooperation Unit, Seoul National University, Korea.

Fernando ES, Quimado MO, Trinidad LC, Doronilla AJ. 2013. The potential use of indigenous nickel hyperaccumulator for small-scale mining in the Philippines. J. Degrad Min Lands Manag. 1 (1): 21-26. DOI: $10.15243 / \mathrm{jdmlm} .2013 .011 .021$

Fernando ES, Quimado MO, Doronila AI. 2014. Rinorea niccolifera (Violaceae), a new, nickel-hyperacummulating species from Luzon Island, Philippines. PhytoKeys 37: 1-13. DOI 10.3897/phytokeys.37.7136

Flora Malesiana Series. 1995-2012. Foundation Flora Malesiana, The Netherlands.

Galey ML,Van der Ent A, Iqbal AMC, Rajakaruna N. 2017. Ultramafic geoecology of South and South East Asia. Bot Stud 58: 18. DOI: 10.1186/s40529-017-0167-9

Garnier J, Quantin C, Guimaraes E, Garg VK, Martins ES, Becquer T. 2009. Understanding the genesis of ultramafic soils and catena dynamics in Niquelándia, Brazil. Geoderma 151 (3-4): 204-214. DOI: 10.1016/j.geoderma.2009.04.020

Green JL, Ostling A. 2003. Endemics-area relationships: The influence of species dominance and spatial aggregation. Ecology 84 (11): 30903097. DOI: 10.1890/02-3096

Killeen TJ, Jardim A, Mamani F, Rojas N. 1998. Diversity, composition and structure of a tropical semideciduous forest in the Chiquitania region of Santa Cruz, Bolivia. J Trop Ecol. 14: 803-827.
Kabata-Pendias A. 2001. Trace Elements in the soil and plants. 3rd ed. CRC Press, Boca Raton, FL.

Langenberger, G. 2004. A Review of Research on Philippine Forest Vegetation, Particularly Work Since 1990. Agham Mindanaw 2: 11 24.

Lewis GJ, Bradfield GE. 2003. A floristic and ecological analysis at the Tulameen ultramafic (serpentine) complex, Southern British Columbia, Canada. Davidsonia 14 (4): 121-134.

Lillo EP, Fernando ES, Lillo MJR. 2019. Plant diversity and structure of forest habitat types on Dinagat Island, Philippines. J Asia-Pac Biodivers. 12 (1): 83-105. DOI: 10.1016/j.japb.2018.07.003

Lumbres RIC, Palaganas JA, Micosa SC Laruan KA, Besic ED, Yun CW, Lee Y-J. 2014. Floral diversity assessment in Alno communal mixed forest in Benguet, Philippines. Landsc Ecol Eng 10: 361-368. DOI: 10.1007/s11355-012-0204-5.

Madulid, DA. 2001. A Dictionary of Philippine Plant Names Vol. II: Scientific Name-Local Name. The Bookmark, Inc., Makati City, Philippines.

Madulid DA. 1991. The endemic genera of flowering plants in the Philippines. Acta Manilana 39: 47-58.

Madulid, DA, Agoo, MG. 1997. Assessment of the vegetation of Philippine mountains on ultramafic rocks. In: Jaffré T, Reeves RD, Becquer T. (eds.) Écologie des Milieux sur Roches Ultramafiques et sur Sols Métallifères. ORSTROM, Noumea.

Madulid DA. 2002. A pictorial guide to the noteworthy plants of Palawan. Palawan Tropical Forestry Protection Programme, Palawan.

Medecilo MMP, Lagat MN. 2017. Floristic composition of the remaining forest in upland Cavite, Luzon Island, Philippines. Philippine J Syst Biol 11 (1): 74-94.

Merrill, E.D. 1923-1926. An Enumeration of Philippine Flowering Plants. Vol. I-IV. Bureau of Printing, Manila, Philippines.

Nkumah PN, Echevarria G, Erskine PD, Van der Ent. 2017. Nickel hyperaccumulation in Antidesma montis-silam: from herbarium discovery to collection in the native habitat. Ecol Res 8: 9683. DOI: 10.1007/s11284-017-1542-4.

Ocon J, Ampan P, Mora-Garcia C, Ciudad KL, Buenaflor EM. 2018. Diversity assessment of floral species and screening of potential nickel hyperaccumulator in nickel-rich Kinalablaban Delta, Cagdianao, Claver, Surigao del Norte, Philippines. J Environ Earth Sci 8 (7): 14-20

Pelser, PB, Barcelona JF and Nickrent DL (eds.) 2011 onwards. Co's Digital Flora of the Philippines. www.philippineplants.org.

Podzorski A. 1985. The Palawan Botanical Expedition: Final report. Hilleshog Forestry AB, Landskrona, Sweden.

Proctor J, Bruijnzeels LA, Baker AJM. 1999. What caused the vegetation types on Mt.Bloomfield, a coastal tropical mountain of the western Philippines. Global Ecol Biogeogr 8: 347-354. DOI: 10.1046/j.13652699.1999.00147.x

Proctor J, Baker JM, Van Balgooy MMJ, Bruijnzeel L, Jones SH, Madulid DA. 2000a. Mount Bloomfield, Palawan, Philippines: Forest on Greyweck and Serpentinized Peridotite. Edin J Bot 57 (1): 121-139.

Proctor J, Baker AJM, Bruijnzeel LA, Van MMJ, Fairweather GM, Madulid DA.2000b. Foliar chemistry and leaf herbivory on Mount Bloomfield, Palawan, Philippines. Bot J Scotland 52: 79-89. DOI: 10.1080/03746600008684946

Proctor J. 2003. Vegetation and soil and plant chemistry on ultramafic rocks in the tropical Far East. Perspect Plant Ecol Evol Syst 61 (2): 105-124.

Quinetala-Sabaris C, Faucon MP,Repin R, Sugau JB, Nilus R, Echevrria $\mathrm{G}$, Leguèdois. 2020. Plant functional traits on tropical ultramafic habitats affected by fire and mining: Insights for Reclamation. Diversity 12: 248. DOI: $10.3390 / \mathrm{d} 12060248$

Rajakaruna N and Baker AJM. 2004. Serpentine: A Model Habitat for Botanical Research in Sri Lanka. Cey J Sci (Bio Sci) 32: 1-19.

Reeves RD. 1992. Hyperaccumulation of nickel by serpentine plants. In: Baker AJM, Proctor J, Reeves RD (eds.). The Vegetation of Ultramafic (Serpentine) Soils. Intercept, Andover.

Reeves RD. 2003.Tropical hyperaccumulators of metals and their potential for phytoextraction. Plants Soil 249: 57-65. DOI: 10.1023/A: 1022572517197

Replan EL, Malaki ABB. 2017. Floral diversity and habitat assessment of Canbantug Forest, Argao, Central Visayas, Cebu, Philippines. Intl J Sci Eng Res 8 (10): 775-780.

Sarmiento RT, Demetillo MT. 2017. Rapid assessment on tree diversity of Nickel Mining sites in Carrascal, Surigao del Sur, Philippines. J Biol Environ Sci 10 (4): 201-207. 
Sarmiento RT. 2020. Floristic diversity of the biodiversity monitoring plots and its environs within Agata Mining Ventures, Inc., Tubay, Agusan del Norte, Philippines. Ambient Sci 7: 1. DOI: 10.21276/ambi.2020.07.1.aa0

Tadesse Z, Kelbessa E, Bekele T. 2017. Floristic composition and plant community analysis of vegetation in Ilu Gelan district, West Shewa Zone of Oromia region, Central Ethiopia. Trop Plant Res. DOI: 10.22271/tpr.2017.v4.i2.045

The IUCN Red List of Threatened Species. Version 2020-1. DOI 10.2305/IUCN.UK.2018-2.RLTS.T125958171A125958179.en

Van der Ent A, Baker AJM, Reeves RD, Pollard AJ, Schat H. 2012 Hyperaccumulators of metals and metalloid trace elements: facts and fiction. Plant Soil 362: 319-334. DOI: 10.1007/s11104-012-1287-3

Van der Ent A, Mulligan D, Erskine PD. 2013. Discovery of nickel hyperaccumulators from Kinabalu Park, Sabah (Malaysia) for potential utilization in phytomining. In: Enviromine 2013, Santiago, Chile, 4-6 December 2013.

Van der Ent A, Erskine P, Sumail S. 2015. Ecology of nickel hyperaccumulator plants from ultramafic soils in Sabah (Malaysia). Chemoecology. DOI: 10.1007/s00049-015-0192-7.

Van der Ent A, Mak R, de Jonge MD, Harris HH. 2018. Simultaneous hyperaccumulation of nickel and cobalt in the tree Glochidion cf. sericeum (Phyllanthaceae): elemental distribution and chemical speciation. Sci Rep 8: 9683. DOI: 10.1038/s41598-018-26891-7.

Xhaferri B, Bani A, Pavlova D, Salihaj M. 2018. Relationship between nickel in the soil and its accumulation by Alyssum murale Waldst \& Kit. during the flowering period at the serpentine site of Pojskë, Albania. Albanian J Agric Sci 17: 384-388. 